\title{
Pengaruh Waktu Aplikasi Paecilomyces spp. terhadap Penekanan Nematoda Bengkak Akar (Meloidogyne spp.) pada Tanaman Tomat (Lycopersicum esculentum Mill.)
}

\author{
Effect of the Application Time of Paecilomyces spp. on the Pressure of Root-Knot \\ Nematodes (Meloidogyne spp.) on Tomato (Lycopersicum esculentum Mill.) \\ Nur Oktafiani Azhar ${ }^{1)}$, Winarto ${ }^{2) *}$, Reflinaldon ${ }^{2)}$ \\ 1) Program Studi Agroteknologi Fakultas Pertanian Universitas Andalas Padang \\ 2) Program Studi Proteksi Tanaman Fakultas Pertanian Universitas Andalas Padang \\ E-mail: winartosmd61@gmail.com
}

\begin{abstract}
The application time of Paecilomyces spp. was assumed affecting its ability to suppress the root knot nematode (Meloidogyne spp.). This study aimed to get the effective application time to suppress Meloidogyne spp. The study was carried out at greenhouse and Biological Control Laboratory of Faculty of Agriculture, University of Andalas from March to June 2015. The research method used was compeletely random design (CRD) with 5 treatments and 4 replications. The application times consisted of 14 days before planting, 7 days before planting, at planting time, 7 days after planting, 14 days after planting and control. Application time of Paecilomyces spp. on 7 days before planting was the best time to reduce the number of root knot, the group of nematode eggs, nematode eggs and nematode larvae in the soil.
\end{abstract}

Keywords: application time, Meloidogyne spp., fungus Paecilomyces spp., tomato

\section{PENDAHULUAN}

Tanaman tomat (Lycopersicum esculentum Mill.) merupakan salah satu komoditas hortikultura yang memiliki nilai ekonomi penting di Indonesia. Tomat merupakan salah satu sayuran yang ditanam di Indonesia, dengan luas lahan lebih dari 5.000.000 ha dan produksinya mencapai 129 juta ton/tahun (Srinivasan, 2010). Di Sumatera Barat, tanaman tomat memiliki produktivitas yang rendah jika dibandingkan Provinsi Sumatera Utara, yang mencapai 27,82 ton/ha (BPS, 2013). Salah satu kendala dalam peningkatan produksi tomat adalah gangguan Organisme Pengganggu tanaman (OPT), antara lain nematoda bengkak akar (Meloidogyne spp.).

Nematoda bengkak akar (NBA) bersifat parasit obligat dan tersebar luas baik pada daerah yang beriklim tropis maupun subtropis. NBA bersifat polifag dengan inang seperti tanaman tomat, kentang, mentimun dan wortel (Sastrahidayat, 1990). Infeksi nematoda pada perakaran tanaman menunjukkan gejala seperti kekurangan hara karena menyebabkan hilangnya kemampuan akar menyerap air dan unsur hara, sehingga tanaman kerdil, mudah layu, daun menguning dan rentan terhadap cekaman lingkungan (Mustika, 2010). Infeksi NBA juga menyebabkan tanaman lebih mudah 
diserang patogen lain seperti bakteri, jamur dan virus. Menurut Hadisoeganda (1991) penurunan produksi tanaman tomat akibat serangan nematoda parasit sebesar $27 \%$ sampai dengan gagal panen.

Salah satu teknik pengendalian NBA yang ramah lingkungan adalah dengan memanfaatkan bionematisida berupa jamur antagonis, seperti Paecilomyces spp. (Prihantoro, 1989; Esser dan El-Gholl, 1993; Winarto et al., 2013; Liswarni, 2014). Ganaie dan Khan (2010) melaporkan bahwa $P$. lilacinus merupakan agen hayati yang potensial untuk mengendalikan $M$. javanica yang menginfeksi tanaman tomat. Menurut Liswarni (2014), aplikasi Paecilomyces $10 \mathrm{~g} /$ tanaman dapat menekan perkembang-an serangan NBA pada tanaman tomat. Oclarit et al. (2009) melaporkan bahwa $P$. lilacinus dengan konsentrasi $3,96 \times 10^{8}$ spora $/ \mathrm{ml}$ mampu menekan serangan $M$. javanica pada tanaman tomat sebesar $95,38 \%$.

Menurut Cabanillas dan Barker (1989), efektivitas Paecilomyces dalam mengendalikan NBA antara lain dipengaruhi oleh umur, virulensi, dan waktu aplikasi. Informasi mengenai waktu aplikasi Paecilomyces yang tepat, sangat dibutuhkan untuk mengoptimalkan penekanan terhadap NBA, baik sebelum tanam, pada saat tanam maupun setelah tanam. Penelitian ini dilakukan untuk mempelajari waktu aplikasi jamur Paecilomyces spp. yang paling tepat dalam menekan serangan NBA pada tanaman tomat.

\section{METODOLOGI}

Penelitian ini telah dilaksanakan pada bulan Maret 2015 sampai Juni 2015 di Nagari Batu Bagiriak Kabupaten Solok Provinsi Sumatera Barat, Laboratorium Pengendalian Hayati dan Rumah Kaca Fakultas Pertanian Universitas Andalas.

\section{Rancangan}

Penelitian ini menggunakan Rancangan Acak Lengkap (RAL) dengan 5 perlakuan dan 4 ulangan. Perlakuan berupa perbedaan waktu aplikasi Paecilomyces spp. yaitu 14 hari sebelum tanam (HBT), pada saat tanam, 7 hari setelah tanam (HST), 14 HST dan kontrol. Paecilomyces spp. yang digunakan merupakan hasil koleksi dari Winarto et al. (2013) di Laboratorium Pengendalian Hayati Fakultas Pertanian Universitas Andalas.

\section{Uji patogenisitas}

Uji patogenisitas dilakukan dengan menyiapkan kelompok telur NBA yang dimasukkan ke dalam cawan petri steril, diberi akuades steril sampai kelompok telur terendam dan didiamkan selama \pm 5 menit. Setelah itu kelompok telur dipindahkan ke dalam cawan petri yang berisi alkohol $70 \%$ dan direndam selama \pm 5 menit, dibilas menggunakan akuades steril agar sisa-sisa alkohol hilang dan direndam kembali selama \pm 5 menit. Kelompok telur NBA diletakkan di atas media PDA pada cawan petri, kemudian diinokulasi dengan suspensi konidia Paecilomyces spp. sebanyak $1 \mathrm{ml}$ diatas permukaan kelompok telur. Paecilomyces spp. yang tumbuh pada permukaan kelompok telur NBA diisolasi dan ditumbuhkan pada media PDA.

\section{Persiapan sumber inokulum telur NBA}

Telur NBA diperoleh dari akar tanaman tomat di Alahan Panjang, Kecamatan Lembah Gumanti Sumatera Barat. Akar tanaman tomat dicuci dan kelompok telur NBA diambil dan dimasukkan ke dalam cawan petri yang sudah berisi akuades. Setiap kelompok telur diletakkan di atas gelas objek dan diberi $\mathrm{NaOCl} 1 \%$ sebanyak 2-3 tetes untuk memisahmisahkan telur dari massanya. Jumlah telur dihitung di bawah mikroskop stereobinokuler.

\section{Perbanyakan dan pembuatan suspensi Paecilomyces spp.}


Biakan jamur Paecilomyces spp. yang digunakan untuk perlakuan waktu aplikasi didapat dari hasil uji patogenisitas. Jamur tersebut kemudian diperbanyak dengan cara menumbuhkan pada media PDA dengan menggunakan cork borer diameter $0,8 \mathrm{~mm}$ dan diinkubasi pada suhu ruang selama 15 hari. Pembuatan suspensi jamur dilakukan dengan menambahkan $10 \mathrm{ml}$ akuades steril ke biakan jamur Paecilomyces spp. di dalam media PDA yang sudah berumur 15 hari, kemudian menambahkan satu tetes agristik 0,05\% sebagai bahan perata ke dalam cawan petri. Konidia yang tumbuh dilepaskan dengan menggunakan kuas halus, kemudian diencerkan (serial dilution) sampai $10^{-3}$

Sebanyak $10 \mathrm{~g}$ dedak beras disterilisasi menggunakan autoklaf selama 15 menit. Sebanyak $1 \mathrm{ml}$ suspensi Paecilomyces spp. dengan konsentrasi $10^{8}$ konidia/ml ditaburkan pada dedak beras, diinkubasi selama 21 hari pada suhu kamar. Kerapatan konidia yang tumbuh pada dedak beras dihitung menggunakan Haemocytometer. Introduksi substrat dedak jamur Paecilomyces spp. ke media tanam dilakukan dua hari setelah introduksi telur NBA dengan cara menghaluskan sebanyak $10 \mathrm{~g}$ substrat dedak secara langsung dengan tangan.

\section{Inokulasi telur NBA ke dalam media tanam}

Media tanam yang digunakan dalam penelitian ini adalah campuran tanah, pasir dan pupuk kandang yang sudah disterilkan dengan perbandingan volume 1:1:1. Sterilisasi media tanam diulang sebanyak 3 kali, dan tanah didinginkan selama 1 hari. Media tanam steril dimasukkan ke dalam polibag ukuran $5 \mathrm{~kg}$ dan diinkubasi di rumah kaca selama 7 hari. Inokulasi telur dilakukan dengan meneteskan cairan akuades yang berisi 300 telur ke lubang tanam.

\section{Penanaman}

Benih tomat yang digunakan adalah varietas Warani ${ }^{\circledR}$. Benih tersebut awalnya disemai pada polibag yang berisi media tanam yang sudah disterilkan. Bibit tomat yang berumur tiga minggu di persemaian, dipindahkan ke polibag yang sudah berisi media tanam. Bibit tomat yang dipilih adalah bibit yang mempunyai ketinggian seragam dan sehat. Pemeliharaan dilakukan dengan penyiram-an pagi dan sore hari dan penyiangan gulma.

\section{Pengamatan}

Pengamatan dilakukan terhadap jumlah bengkak akar/ tanaman, jumlah kelompok telur/ tanaman, jumlah telur per kelompok telur, dan jumlah larva nematoda. Jumlah bengkak akar dan jumlah kelompok telur dihitung dari setiap akar tanaman tomat pada masingmasing perlakuan. Jumlah telur per kelompok telur dihitung dengan mengambil sampel sebanyak 5 kelompok telur/tanaman. Tiap kelompok telur diletakkan di atas gelas objek dan diberi $\mathrm{NaOCl}$ 5,25 \% sebanyak 2-3 tetes tiap sampel, lalu diamati dibawah mikroskop stereobinokuler dan dihitung dengan mesin penghitung. Jumlah larva nematoda dihitung setelah melalui ekstraksi $30 \mathrm{~g}$ tanah per polibag menggunakan corong Baermann yang telah dimodifikasi.

Untuk melihat pengaruh waktu aplikasi Paecilomyces spp. terhadap penekanannya pada jumlah bengkak akar, jumlah kelompok telur, jumlah telur dalam kelompok telur dan jumlah larva nematoda dalam sampel tanah, digunakan rumus Oclarit and Cumagun (2009) sebagai berikut:

$E=\frac{K-P}{K} \times 100 \%$

Keterangan:

$\mathrm{E}=$ Kemampuan penekanan 
$\mathrm{P}=$ Perlakuan

$\mathrm{K}=$ Kontrol

\section{Analisis data}

Data yang di peroleh dari pengamatan, dianalisis secara statistik dengan sidik ragam dan dilanjutkan dengan uji Least Significance Different (LSD) taraf $5 \%$.

\section{HASIL}

Tabel 1 Jumlah bengkak akar tanaman tomat pada masing-masing waktu aplikasi Paecilomyces spp. pada 45 hari setelah tanam

\begin{tabular}{lcc}
\hline \multicolumn{1}{c}{ Perlakuan } & $\begin{array}{c}\text { Jumlah bengkak akar } \\
\text { (buah/tanaman) }\end{array}$ & $\begin{array}{c}\text { Kemampuan Penekanan } \\
\text { (\%) }\end{array}$ \\
\hline A. Tanpa Perlakuan (Kontrol) & $256,50 \pm 31,75 \mathrm{a}$ & - \\
F. 14 Hari setelah tanam & $88,50 \pm 10,08 \quad$ b & $65,49 \%$ \\
E. 7 Hari setelah tanam & $85,25 \pm 8,99 \quad$ b & $66,76 \%$ \\
D. Saat tanam & $79,00 \pm 4,32 \quad$ bc & $69,20 \%$ \\
B. 14 Hari sebelum tanam & $59,50 \pm 2,08 \quad$ cd & $76,80 \%$ \\
C. 7 Hari sebelum tanam & $46,50 \pm 5,80 \quad$ d & $81,87 \%$ \\
\hline
\end{tabular}

Angka-angka pada lajur yang sama diikuti huruf kecil yang sama berbeda tidak nyata pada taraf $5 \%$

Jumlah kelompok telur

Waktu aplikasi Paecilomyces spp. mempengaruhi jumlah kelompok telur NBA pada akar tanaman tomat. Aplikasi yang dilakukan dari saat tanam sampai 14

\section{Jumlah bengkak akar}

Waktu aplikasi Paecilomyces spp. mempengaruhi jumlah bengkak akar yang muncul pada akar tanaman tomat. Aplikasi yang dilakukan 7-14 hari sebelum tanam lebih efektif dibandingkan aplikasi 7-14 hari setelah tanam. Persentase penekanan tertinggi terjadi pada aplikasi 7 hari setelah tanam $(81,87 \%)$ (Tabel 1$)$.

Tabel 2 Jumlah kelompok telur nematoda pada tanaman tomat masing-masing waktu aplikasi jamur Paecilomyces spp. diamati 45 hari setelah tanam

\begin{tabular}{lcc}
\hline \multicolumn{1}{c}{ Perlakuan } & $\begin{array}{c}\text { Jumlah kelompok telur } \\
\text { (buah/tanaman) }\end{array}$ & $\begin{array}{c}\text { Kemampuan Penekanan } \\
\text { (\%) }\end{array}$ \\
\hline A. Tanpa Perlakuan (Kontrol) & $30,25 \pm 5,44$ a & - \\
F. 14 Hari setelah tanam & $20,25 \pm 4,03 \quad$ b & $33,06 \%$ \\
E. 7 Hari setelah tanam & $17,50 \pm 2,38 \quad$ b & $42,15 \%$ \\
D. Saat tanam & $12,00 \pm 2,16 \quad$ c & $60,38 \%$ \\
B. 14 Hari sebelum tanam & $10,50 \pm 2,08 \quad$ c & $65,29 \%$ \\
C. 7 Hari sebelum tanam & $8,25 \pm 1,71 \quad$ c & $72,73 \%$ \\
\hline
\end{tabular}

Angka-angka pada lajur yang sama diikuti huruf kecil yang sama berbeda tidak nyata pada taraf $5 \%$.

\section{Jumlah telur/ kelompok telur}

Waktu aplikasi Paecilomyces spp. mempengaruhi jumlah telur/kelompok telur NBA pada akar tanaman tomat. Aplikasi yang dilakukan dari saat tanam hari sebelum tanam lebih efektif dibandingkan aplikasi 7-14 hari setelah tanam. Persentase penekanan tertinggi terjadi pada aplikasi 7 hari sebelum tanam (72,73\%) (Tabel 2)

Tabel 3. Jumlah telur per kelompok telur nematoda pada tanaman tomat masing-masing

waktu aplikasi Paecilomyces spp. diamati 45 hari setelah tanam.

Perlakuan sampai 14 hari sebelum tanam lebih efektif dibandingkan aplikasi 14 hari setelah tanam. Persentase penekanan tertinggi terjadi pada aplikasi 7 hari sebelum tanam (66,75\%) (Tabel 3).

telur (butir/kelompok telur)




\begin{tabular}{lcccc}
\hline A.Tanpa Perlakuan (Kontrol) & $207,50 \pm 42,52$ a & & - \\
F. 14 Hari setelah tanam & $160,00 \pm 42,83$ & b & $22,89 \%$ \\
E. 7 Hari setelah tanam & $112,00 \pm 15,9$ & c & $46,02 \%$ \\
D. Saat tanam & $95,25 \pm 11,32$ & cd & $54,22 \%$ \\
B. 14 Hari sebelum tanam & $87,25 \pm 8,73$ & cd & $57,95 \%$ \\
C. 7 Hari sebelum tanam & $69,00 \pm 12,06$ & d & $66,75 \%$ \\
\hline
\end{tabular}

Angka-angka pada lajur yang sama diikuti huruf kecil yang sama berbeda tidak nyata pada taraf $5 \%$.

Jumlah larva nematoda dalam tanah

Waktu aplikasi Paecilomyces spp. mempengaruhi jumlah larva NBA pada akar tanaman tomat. Aplikasi yang dilakukan dari 7-14 hari sebelum tanam lebih efektif dibandingkan aplikasi 7-14 hari setelah tanam. Persentase penekanan tertinggi terjadi pada aplikasi 7 hari sebelum tanam (65,98\%) (Tabel 4).

Tabel 4 Jumlah larva nematoda dalam tanah pada tanaman tomat masing-masing waktu aplikasi jamur Paecilomyces spp. diamati 45 hari setelah tanam.

\begin{tabular}{lcc}
\hline \multicolumn{1}{c}{ Perlakuan } & $\begin{array}{c}\text { Jumlah larva nematoda } \\
\text { dalam tanah (ekor/300 g } \\
\text { tanah) }\end{array}$ & $\begin{array}{c}\text { Kemampuan Penekanan } \\
\text { (\%) }\end{array}$ \\
\hline A.Tanpa Perlakuan (Kontrol) & $24,25 \pm 5,74$ a & - \\
F. 14 Hari setelah tanam & $20,75 \pm 3,50 \mathrm{ab}$ & $14,43 \%$ \\
E. 7 Hari setelah tanam & $15,75 \pm 4,03 \mathrm{abc}$ & $35,05 \%$ \\
D. Saat tanam & $12,00 \pm 3,74 \quad \mathrm{~cd}$ & $50,52 \%$ \\
B. 14 Hari sebelum tanam & $10,25 \pm 1,26 \quad \mathrm{~d}$ & $57,73 \%$ \\
C. 7 Hari sebelum tanam & $8,25 \pm 1,71 \mathrm{~d}$ & $65,98 \%$ \\
\hline
\end{tabular}

Angka-angka pada lajur yang sama diikuti huruf kecil yang sama berbeda tidak nyata pada taraf $5 \%$.

\section{PEMBAHASAN}

Waktu aplikasi Paecilomyces spp. mempengaruhi jumlah bengkak akar, jumlah kelompok telur, jumlah telur/ kelompok telur, jumlah larva dari NBA dan jumlah propagul Paecilomyces spp pada akar tanaman tomat. Waktu aplikasi Paecilomyces spp. 7 hari sebelum tanam mempunyai kemampuan penekanan paling efektif terhadap NBA dibandingkan waktu aplikasi lainnya. Hal ini berbeda dengan temuan Cabannillas dan Barker (1989) yang menyatakan bahwa waktu aplikasi $P$. lilacinus 10 hari sebelum tanam adalah waktu yang tepat dalam menekan Meloidogyne. Menurut Al kader (2008), Paecilomyces mampu menginfeksi telur setelah empat hari diinkubasi. Bonants et al. (1995) melaporkan bahwa jamur Paecilomyces dalam proses infeksinya mengeluarkan enzim protease yang dapat menghancurkan telur nematoda empat hari setelah inkubasi. Lama waktu yang dibutuhkan selama proses infeksi jamur Paecilomyces spp. dipengaruhi pula oleh kondisi lingkungan.

Waktu aplikasi 7 hari sebelum tanam lebih baik dibandingkan 14 hari sebelum tanam. Hal ini diduga dipengaruhi oleh adanya kompetisi antara Paecilomyces spp. dengan jamur lain di dalam tanah. Sesuai dengan pernyataan Mulyadi (2009) bahwa mikroba tanah dapat berperan sebagai pesaing jamur antagonis nematoda dalam mendapatkan makanan dan ruang. Waktu aplikasi 7 hari sebelum tanam merupakan waktu yang tepat bagi jamur Paecilomyces spp. untuk menginfeksi massa telur nematoda dan larva yang sudah menetas. Hal ini juga disebabkan Paecilomyces spp. masih memiliki nutrisi substrat dedak. 
Menurut Nurbailis dan Martinius (2011), bahan organik sebagai makanan dasar dan pembawa jamur antagonis berpengaruh terhadap daya adaptasi dan peningkatan kepadatan populasi jamur setelah diintroduksikan ke dalam tanah. Ingold (1967) menyatakan bahwa nutrisi dan lingkungan mempengaruhi pertumbuhan jamur dalam membentuk miselium atau struktur reproduksi.

\section{KESIMPULAN}

Waktu aplikasi jamur Paecilomyces spp. 7 hari sebelum tanam merupakan waktu yang paling efektif dalam menekan bengkak akar, kelompok telur, telur dalam kelompok telur, dan larva nematoda dalam tanah pada tanaman tomat yang terserang nematoda bengkak akar (Meloidogyne spp.)

\section{DAFTAR PUSTAKA}

Al Kader MAA. 2008. In vitro studies on nematode interaction with their antagonistic fungi in the rhizosphere of various plants. [Thesis]. AlbertLudwig-Univ. Germany.

Bonants PJM, PFL Fitter, $H$ Thijs, ED Belder, C Waalwijkan dan Henflings JWDM. 1995. A basic serine protease from Paecilomyces lilacinus with biological activity against Meloidogyne hapla eggs. Journal of Microbiology 141 (4): 775-784.

BPS. 2013. Produksi sayuran di Indonesia tahun 1977-2012.

Cabanillas E dan KR Barker. 1989. Paecilomyces lilacinus inoculum level and application time on control of Meloidogyne incognita on Tomato. Journal of Nematology 21(1): 115-120.

Esser RP dan NE El-Gholl. 1993. Paecilomyces lilacinus, a fungus that parasitizes nematode eggs. Dept. Agr. and Consumer Serv. Nematolgy Circular No. 203.
Ganaie MA dan TA Khan. 2010. Biological potential of Paecilomyces lilacinus on phatogenesis of Meloidogyne javanica infecting tomato plant. Journal of Applied Sciences 2(2): 8084.

Hadisoeganda AW. 1991. Pancaran, identifikasi dan prevalensi nematoda bengkak akar di sentra daerah penanaman sayuran dataran tinggi di Indonesia. Buletin Penelitian Hortikultura 20 (3): 62-71.

Ingold CT. 1967. The biology of fungi. Second Edition. Hutchinsor and Co Ltd. London.

Liswarni Y. 2014. Pengujian dosis jamur Paecilomyces sebagai bionematisida untuk pengendalian nematoda bengkak akar (Meloidogyne spp.) pada tanaman tomat. Penelitian Dosen Muda. Fak.Pertanian. Univ. Andalas. Padang.

Mulyadi. 2009. Nematologi pertanian. Gadjah Mada University Press: Yogyakarta.

Mustika I. 2010. Konsepsi dan strategi pengendalian nematoda parasit tanaman di Indonesia. [short communication]. Pusat Penelitian dan Pengembangan Perkebunan 3(2): 81-101.

Nurbailis dan Martinius. 2011. Pemanfaatan bahan organik sebagai pembawa untuk peningkatan kepadatan populasi Trichoderma viridae pada rizosfir pisang dan pengaruhnya terhadap penyakit layu Fusarium. Jurnal HPT Tropika 11 (2): 177-184.

Oclarit EL dan CJR Cumangun. 2009. Evaluation of efficacy of Paecilomyces lilacinus as biological control agent of Meloidogyne incognita attacking tomato. Journal of Plant Protection Research 49 (4): 337-340. 
Prihantoro. 1989. Penggunaan jamur Paecilomyces sp. sebagai pengendali nematoda puru akar. Perhimpunan Fitopatologi Indonesia. Denpasar.

Sastrahihayat IR. 1990. IImu penyakit tumbuhan. Penerbit Usaha Nasional. Surabaya. Sayre, R.M. 1980. Promising organism for biological control of nematodes. Plant Disease 64: 527-532.

Srinivasan R. 2010. Safer tomato techniques; a field guide for soil fertility and pest management. AVRDC Publication Report.

Winarto, Trizelia dan Y Liswarni . 2013. Pengembangan formula jamur bionematisida untuk pengendalian nematoda bengkak akar (Meloidogyne spp.) pada tanaman tomat. Laporan Penelitian Hibah Bersaing. Lembaga Penelitian dan Pengabdian Masyarakat Universitas Andalas. Padang. 